\title{
Religion: A Vital Element for Curbing the Menace of Kidnapping in Nigeria for Human Development
}

\author{
Faith Nkem Okobia \\ http://dx.doi./org/10.4314/ujah.v18i2.20
}

\section{Abstract}

Human capital development has been the most powerful tool for national development; however, Nigeria has been weighed down by the menace of kidnapping which is militating against human development. Kidnapping of people for ritual or extortive or ransom purposes cut across all classes of people - children, foreign workers, traditional rulers government officials, religious leaders medical practitioners, lecturers, politicians and some commoners. This phenomenon has enriched the perpetrators who now contend with the nation in the arena of legitimate use of force and monopoly of violence. The menace of kidnapping is a reflection of moral decadence in Nigeria hence the need for religious studies which inculcate the right moral values such as honesty, hard work, value for life and good human relations which generate peace in the society. It also infuse sanity into the fast decaying nation, prevent the citizens from being social deviant, curb kidnapping and enhance human development. The aim of this paper is to emphasize on the importance of religious studies in curbing the menace of kidnapping. The method used in gathering information concerning this work is the secondary source such as text books, newspapers and electronic media. Findings show that poverty, social; deprivation, frustration - aggression unemployment, lack of youth empowerment and lack of moral values in the lives of many youth led to the menace of kidnapping there should be provision of employment and empowerment 
opportunities for youth and Religious bodies and the government should educate the masses on the sanctity of life and good human relations.

Keywords: Religion, Human development and kidnapping

\section{Introduction}

In Nigeria today, one of the issues that is given everybody a serious concern is kidnapping or hostage taking for ransom and ritual purposes which is the manifestation of moral decadence in the society. Therefore, for a total stamp out of kidnapping in Nigeria, morality which is embedded in religion has to be fused into the lives of the populace. Furthermore, religion has been an advocate for the development of people all over the world. The early education bodies were instituted to instruct church leaders on the best methods of human development.

Therefore, religion builds a conceptual framework on which many human qualities are developed. Kidnapping in Nigeria which provokes intellectual curiosity first attracted national and international attention on February 26, 2006. This was when some Niger Delta militants kidnapped foreign oil workers to drive home their resource-control demands. This form of kidnapping falls within 'grievance-expression kidnapping' or social deprivation. It was in this light that some scholars traced the root cause and rise in kidnapping in Niger Delta to "natural resource nationalism" the tendency to seek bigger shares of the returns from natural resources, and a way of measuring the yawning gap between the region's natural endowment and their existential reality, Akpan and Akpabio (2003) observed that its potential for sustainable development remains unfulfilled, and is now threatened by 
environmental devastation and worsening economic conditions. They argue further that despite these, the inhabitants remain very poor while their source of livelihoods depends on the natural environment oftentimes devastated and degraded by oil production-exploration, exploitation, gas flaring, and concomitant environmental pollution. To the militants, kidnapping happens to be the only industry of last resort aimed at forcefully getting a share of region's wealth (Akpan, 2010). Consequenctly, the militants decided to be holding both local and expatriate workers hostage as bargaining chips to free themselves of poverty. This form of freedom from poverty is akin to securing 'an illusory compensation' for a region so rich yet so ravaged by poverty and characterized by a devastated, polluted and degraded environment.

According to Obakhado (2015), at the initial stage of kidnapping and hostage taking in the Niger Delta region, the Nigerian Presidency with some Niger Delta Governors were involved in negotiating with the kidnappers to assuage the anger of the armbearing militants, for instance, President Obasanjo pleaded with the Niger Delta Governors to help curtail phenomenon and they ended up becoming the Chief Negotiators between the Federal Government of Nigeria, the Multi-national corporations and the Niger Delta Militants (Adejumo, 2010). For the negotiators, it became a very lucrative business though risky because of the insincerity and duplicity involved. For example, if the kidnappers demanded Five Hundred Million Dollars (\$500,000 Million), and the ransom is paid, the Chief Negotiator will collect this money from the particular oil company and share it with the militants, with the Negotiator taking the larger share in most cases (Adejumo, 2010). 
But it is important to stress that the lucrative nature of this first phase of kidnapping was to open the way for another form of kidnapping which does not have anything to do with resourcecontrol. From that time till date, kidnapping has become everyone's nightmare as the gale of pervasive kidnapping and hostage-taking now sweeps across the length and breadth of the country with the south-east and south-south geo-political zones as the hottest-spots (Adibe, 2010). This form of kidnapping which is economic or extortive in nature is discovered to have a relationship with unemployment, poverty, corruption, greed, illiteracy and other variables which manifest in form of abnormal behavior in Nigeria.

This prompted Akpan (2010) to posit that the political importance of kidnapping activity has had a spill-over influence on the jobless youths and criminals who take it as a new substitute or complement to robbery and pick-pocketing. To him, such a group of kidnappers target not only prominent and wealthy individual but also ordinary citizens who possess little wealth, and their common targets include every perceived person with prospects of high and lucrative ransom including teenagers, children and adults alike. He contends that robbers and other criminal groups have taken advantage of this as a new way of making a living or sustaining their living standard or strengthening their networks. To this end, the voice of America (2009) concludes that what started like a joke in the Delta region has spread to other parts of the country, with South-East as the worst flash points with kidnapping of foreigners and wealthy Nigerians and other forms of violent crimes as the common characteristics 


\section{Origin of Kidnapping in Nigeria}

Kidnapping is a universal phenomenon that poses a challenge to humanity, but the way one falls victim depends on the society, especially the nature of the social structures and the moral value of the people in such environment kidnapping is not new in Africa but it does appear to be increasing in Nigeria. The nation Nigeria, as we know it today was not in existence at the time of slave trade, but the various people that form part of the geo-political enclave now referred to as Nigeria were fully involved in the sad experience either as agents or victims of slavery. According to Elu (1998), Nigeria accommodated slavery as part of property owned by the wealthy especially royal homes. Kidnapping had been a part and parcel of the Nigerian society apart from the slave trade. The extra-judicial abduction and false imprisonment by the subsequent military government are clear indications of these realities. In this regard all manner of unlawful detentions and arrest that may not require ransom before release are still within the umbrella of kidnapping.

Yet, kidnapping in modern Nigeria can be said to be an out come of the "Resentment against inhuman treatments and poverty in the Niger Delta of the country" Ulebo, (2011). Kidnapping was unleashed in Port-Harcourt on February 18, 2006 by militants to drive home their demands. It was a means of drawing local and international attention to the underdevelopment, environmental degradation and plight of the inhabitants of the area, Ijediogor, (2010). States that the basic objectives of the kidnappers of foreign oil workers were identifiable because at the beginning ransom were hardly demanded and rarely paid since it was not geared towards economic gains but as a means to drive home their point on the struggle for the region. This business venture and money 
making crime of kidnapping moved from Port-Harcourt and indeed South-South geopolitical zone to South-Eastern states, and others got contaminated, perhaps through the process of social osmosis occasioned by interaction and association.

\section{Causes of Kidnapping in Nigeria}

Kidnapping exercise is not an incidental one rather a planned one and as such with criminal intent (Ukandu, 2011). A wide range of causative factors are responsible for the kidnapping that troubled the good people of Nigeria. These factors can view distinctively, yet they are intrinsically linked to one another as one concept directly leads to another. They include moral and spiritual bankruptcy, cultism unemployment and poverty, government poor attitude to crime control, collaboration with criminals, proliferation of arms and a share from the amnesty grant to the Niger-delta youth.

\section{Moral Bankruptcy}

Social norms which hold society together, acquire their binding sense and norms of sacredness from religion. Every religion encompasses moral code that stipulates the dos and don'ts for the regulation of human conduct, Onyeidu (2001). A life nurtured in sensitivity to self, others and God is the hallmark of human blessedness, especially when the search for direction and meaning culminates at self-development and a proper understanding of human psychology. These requirements for a healthy society seem to be on the want in Nigeria, especially where the people tend to say nothing and do nothing about the moral virtues of the citizens. Okwu (2003) had noted that, morality as an important ingredient of living in human society, is increasingly being abandoned in private and public life in our society. He cited examples from news reports 
on cult killings, armed robbery, assassination and murder. Kidnapping is a pointer to moral anarchy in Nigeria. Moral anarchy is an indication of the decline of religion. Amzat, (2010) states that the cultist and the kidnappers are mostly youths, who belonged to one cult or the other and have some of their fellow cultists in high places in the government. Kidnapping is a criminal network allover Nigeria that draws largely on individuals with particular skills mainly from cult groups. The level of perfection and sophistication employed in carrying out kidnapping is a pointer to violent orientation gained by cult members at their school days.

\section{Unemployment and Poverty}

According to Nwosu (2009), one of the factors that promote violent crimes in Nigeria is the socio-economic order that sustains widespread poverty and unemployment of youths in Nigeria. Moreover he stressed that a nation that has few wealthy ones and the lager majority wallowing in abject poverty and degradation creates room for ill-feeling and suicidal instincts. Adding that, a socio-economic system that creates a great wide gulf between the haves and the have-nots cannot but become a nurturing ground for evil acts as evident in Nigeria today. Socio-economic order that promotes materialism as the prime value of the society no doubt will experience crimes as the case with Nigeria. Against this backdrop any nation that operates socio-economic order that fosters wealth accumulation by the political class at the expense of equity, productivity, justice, fair play and respect for human rights of the citizens as well as rule of law must sooner or later become a breeding ground for violent crime and instability. 


\section{Government Poor Attitude to Crime Control}

According to Ajah (2009) government poor attitude to crime control is another reason while violent crimes have remained on the increase in Nigeria, not that Nigeria has not been blessed with good leaders who are committed to fighting crime by ensuring that full weight of that law are employed on law offenders. He stressed that our government no longer pays attention to the primary functions of providing security, neither do they listen to the plight of the poor masses. Commenting on government poor attitude to crime prevention and control, Umeagbalasi (2011) posits that it is unfortunate that in some cases when real perpetrators are arrested, they are hurriedly released at the instance of "order from above". Amaefule (2010) opines that one of the factors responsible for the growth of violent crimes like kidnapping in Nigeria is due to the failure or poor attitude of the government to address the problem when it was evolving, noting that when the government failed to tackle the challenges that it faced, the crime grew into larger proportions. What this translates is that the government in most cases lacks the will to deal decisively with security challenges in the nation, because of their overt and convert interest. As a result justice is not only delayed but in most cases denied as criminals go about having a field day in the business of crimes.

\section{Collaboration with Criminals}

Amaefule (2010) asserts that another major factor that promotes kidnapping in Nigeria is the activities of collaborators. The situation where some members of national security agencies like the Nigeria Police collaborate with kidnappers and armed robbers with whom they share their ransom, cannot but foster insecurity in the country. It is most worrisome to hear the police advice some victims of kidnap to cooperate with kidnappers by paying the 
demanded sum instead of helping victims to get kidnappers arrested and handed over to relevant authorities for adequate punishment. Adesina (2009) posits that the increasing atrocious crime called kidnapping in Nigeria has once again brought to fore the allegation of complacity of some members of police force with criminals to aid and abate violent crimes.

\section{Types of Kidnapping}

\section{Bride Kidnapping or Force Marriage}

Force marriage, marriage by capture or bride kidnapping is an act of forcefully taking a girl or woman to be a wife without fulfilling the marital rites and requirements of her people especially their native laws and customs. It is a situation where a man that has an intention to marry a girl or woman faces some manner of challenges ranging from issues of social class, poverty, sickness, disease among others and chose to capture the bride even without her consent. The practice has an overriding sex crime aimed at impregnating the girl or woman to ensure she remains in the forcefully acquired relationship so that if they return to the bride's family they will have no reservations on the continuity of the union. This practice of bride kidnapping is a clear negation of the core value and it obliterates the customary law of the people as marriage is viewed as an agreement that proceeds from the mutual consent of both spouse and receives the approval of their parents. Although, cases abound where couples may connive and elope from their parents or guardians owing to the challenges that threatens their union. Yet, the emphasis of kidnapping for marriage purpose or bride kidnapping is the unwillingness or lack of consent by the girl or woman. 


\section{Kidnapping for Ritual Purpose}

Ritual kidnapping is relatively old practice in African context. Human sacrifices are not new in the annals of traditional sacred practices especially for the cleansing of lands from curses that come along with the situations of drought, famine and barrenness. It entails the forceful abduction of women, young men and children especially for the purpose of using them to appease or ritually cleanse a community or put to end sufferings of people or person. (2010) States that in traditional Nigerian societies, individuals were mostly, kidnapped for ritual purpose of sacrifice either to appease the gods or for the burial of a prominent king, chief or warrior. Ritual kidnapping is a tool employed to get the required human agents needed for ritual purposes. Some of these kidnapping were carried out at the middle of the night while others in the broad day light.

For the achievement of fame several occults groups, secret societies may demand a number of life that must be provided for the specific ritual. These lives are not just sought out for, rather specific human age, sex and on other case the level of human purity is taken into cognizance. Here, people of pure nature or virgins are demanded and on other occasions, vital human parts such as eyes, tongue, breast, male penis or female virginal. According to Abati (2009) Nigerians have always talked about how human parts are sold for money-making rituals or to acquire spiritual power or social menace of child theft that will lead our minds to "Clifford Orji" and the sale of human parts. The end purpose for ritual kidnapping has been viewed in most cases as a means to material wealth and physical protection from danger. In contemporary times, one can view these means of kidnapping as an important step in becoming wealthy in the society were desperate 
politicians will have to meet whatever requirement for them to be rich. No wonder (2010) was explicit when he states that "kidnapping for ritual purpose may also have some social, monetary or economic objectives". By promoting a culture of wealth and materialism people have sought for through the lives of innocent human beings.

\section{Kidnapping as a Political Tool}

According to Ukandu (2011), some kidnapping owe their prime motivating factor on political end, by political end it implies the struggle to power and state resource attainable through competition and strategic opposition. Kidnapping could be politically motivated as some politicians would employ the services of some kidnappers to intimidate or eliminate their opponents while others who are not good at politicking and lacks the political skill of bargaining or buying the voters, resort to kidnapping and political killings (Nyam, 2010). "kidnapping now is used as a weapon of political intimidation" top political opponents. Highly placed government figure and politicians often mingle with criminals, providing them with the required protection and boldness to commit violent crimes in the society. Kidnapping have been used partly as a political tool to gain attention and a means of getting financial incentives and achieving political ambitions. He further cautioned that kidnapping and hostage taking may become the preferred tactics of political terrorists.

\section{Kidnapping for Economic Reasons}

Ransom kidnapping is a broad term for all abductions that owe their motivation from the amassment of wealth. Kidnapping for economic reasons has its emphasis on cash generation for the meeting of needs and satisfaction of material pleasures. 
Kidnapping for economic reasons is a major source of livelihood, for some criminal minded youths who use kidnapping to make a living as it seems to be on the fast lane (Nyam, 2010). Unemployment is a bane to insecurity in the society as the need to satisfy hunger, is a chief propelling factor that attracts the jobless to this trade with its high incentive. The poor, who are often unemployed and hungry, seek opportunities to kidnap the relatives of politicians, well to do business men, government workers and who ever look capable of generating the desired ransom after a bargain. Although, these ransoms are construed as punishment to the perceived rich, its purpose has become commercial and boarders on criminality (Ijediogor, 2010). Kidnapping is national crime and it is thriving because those who engage in it see it as a lucrative business with immense reward and less hazards.

The economic attractiveness of kidnapping as a criminal rebellion has sustained the vices since the returns when balanced against the chance of doing the trade with all seriousness. As Adeyemi (2010) has it that, the face of the failure of security system, kidnapping has grown into full blown commercial venture and it is no longer a protest act against perceived social and economic injustice. Kidnapping is a big business, motivated by profit and not principle. Economic kidnapping is a fast growing criminal industry in Nigeria.

\section{The Effects of Kidnapping}

Kidnapping is detrimental to the general well being of the populace. The following are the effects of kidnapping

1. It creates fear of insecurity that leads to high blood pressure, cardiac arrest and other sicknesses that can reduced the life 
span of the victims and the neighbours around which hinders human development.

2. It causes loss of lives and property. Some of the victims of kidnappers died in the process and this leads to shortage of man power and hinders human development.

3. Lose of money or material resources: The money government would have used for development are paid to kidnappers as ransom. Also the victims paid through their nose and reduced some of them to pauper.

4. The endemic nature of kidnapping has made the country beyond the borders of development as everything seems to be on the halt.

5. The payment of ransom has made some youth to consider it, a lucrative business, thereby enthroning a culture of violence in place of hard work and dignity of labour.

6. Violent crime, like kidnapping poses a threat to internal security because it causes disruption of order and distortion of public safety and security.

7. It discourages the foreign investors from investing in the country.

\section{The Role of Religion in Curbing Kidnapping}

i. Religion promotes human development by inculcating essential values which humanity in general consider as important to the enhancement of order, peace, progress, happiness, protection of the weak and the invalid, social cohesion and solidarity.

ii. According to Ubrurhe (2000), Religion helps to curb kidnapping, because it patterns man's behavior in agreement with the societal norms and values which promotes societal stability and enhance human development. 
iii. Religion binds people together through sanctions which include scolding, criticism, ostracism, excommunication and final judgment of God and its attendant consequences. As a result of these, people are forced to fulfill societal obligations in accordance with accepted norms and values.

iv. Adogbo (2000) states that Religion inculcates justice, truth, equity, sanctity of life into its adherents which helps to fight against kidnapping and promote human development.

\section{Conclusion}

Nigeria as a nation is suffering economic woes as a result of kidnapping, because it. deters development. As a result of kidnapping, most of our foreign investors are scared away because of the hostile environment brought about by unabated kidnapping. Therefore, to avoid premature death of the criminals and their victims which lead to shortage of man power and hinders human development. Serious effort should be made to curb kidnapping to enhance security in the nation. Nigerians are faced with the challenges of insecurity as youths who have poor background in education and have no place where they can be gainfully employed, make themselves readily available for recruitment to the local militia to kidnap people which will make them or their victims to lose their lives which hinders human development. Therefore, Nigerians have to promote and embrace religion in the society since religion plays a very critical role in the social lives of the people by inculcating good morals, such as hard work self discipline, respect for life and good human relations because a morally conscious man will not be involved in this vice. Therefore, the youth should shun kidnapping, to avoid premature death which hinders human development. 


\section{Recommendations}

The cost of curbing kidnapping is quite high both for individuals as well as the nation because they disrupt human development and interfere with people's ability to develop their full potentials which as well hinders national and human development. The mind and energy of the average Nigerian is consumed with issues of kidnapping, safety and security that he or she has little energy left to develop himself and contribute to Nigerian's development. Nigerians need a country that is stable, peaceful and safe enough from kidnapping, criminal assaults, murder, chaos, tyranny and breakdown of authority so that the populace can face issue of development with vigour and courage. To attain such height, the under listed recommendations are suggested.

$>$ The religious bodies and government should liase together in the inculcation of good moral into the populace in order to enhance security and eradicate kidnapping in the society.

$>$ Government should lay more emphasis on the teaching of religious education at all levels of education to inculcate good moral into the youths to avoid kidnapping and insecurity in the society and enhance human development.

$>$ Religious bodies and the government should educate the masses on good human relations in order to shun kidnapping in the society.

$>$ Governments at all levels should ensure that rising poverty indices be reversed and social security programmes be pursued to ensure that the populace meet their basic needs.

$>$ There should be a re-organization of the security agencies that will take them through a new reorientation via-training of security agents. People should be more security conscious, share information with the police and other security agencies. The populace should not leave security matters to security 
personnel only. All should be involved in security information and data gathering. Moreover, efforts should be put in crime prevention than control.

$>$ Furthermore, the government should increase the size of Nigeria's security agencies, empower and motivate them very well and strengthen neighbourhood watch. Government should equally fix social infrastructures-roads, street lights, schools and skill acquisition centres.

- Apart from the above, there is no gain saying that lack of youth empowerment programmes contributed immensely to insecurity in the nation. The government should create youth empowerment centre for them to be gainfully employed and divert their minds from criminal tendencies.

Faith Nkem Okobia

College of Education, Agbor nkembia80@yahoo.com

\section{References}

Abati, R. (2009). Ransom Kidnapping, Hostage Taking and a Bewidered Nigeria. Lagos: Richard way.

Ajah, C. (2009). Menace of kidnapping, Daily Sun December 23 p.18.

Ameafule, E (2010). Jonathan Rules out National conference. The punch December, 20 pp. 30-31.

Amzat, A (2010). Kidnapping and the falling state status of Nigeria. The Guardian. P. 10.

Elu, W. (1998). Nigeria's growing kidnap industry. Lagos: Brightway. 
Hornby A.S (2005). Advanced Learners Dictionary of current English. Oxford: Oxford University.

Nmah, P.E. (1998). Religion and society in Africa. Enugu: Rabboni.

Nogbu, R (2008). Ransom kidnapping and Hostage taking in Nigeria. Lagos: Wisdom

Obakhedo, M.E. (2015). Manifestations of state failure. The case of kidnapping in Nigeria. Ekpoma Journal of social sciences, 6 (2), pp. 230-231.

Oke, B (2010). The purpose of kidnapping. Owerri: Prince.

Okwu, E.Z (2003). Crime Control Stratagies. New York: Graw Hill.

Turner, M. (1998). Kidnapping and politics. International Journal of sociology of law, 2(6), pp. 145-146.

Ubrurhe, J.O. (2000). Nigerian People and Culture. Warri: Foresight.

Ukandu, I.M. (2011). The menace of kidnapping. Abia: Eagle.

Ulebo, S.A (2011). Crime and its effects. Ikeja: Star.

Umeagbalasi, A.B. (2011). Insecurity and its effects in Nigeria. Lagos: Peak. 